1

\title{
How and When Matter: Exploring the Interaction Effects of High-Performance Work Systems, Employee Participation, and Human Capital on Organizational Innovation
}

\author{
Yu Zhou* \\ Associate Professor \\ Department of Organization and Human Resources | School of Business \\ No. 59 Zhongguancun Street, Haidian District \\ Renmin University of China, Beijing 100872 China \\ T: +861062513473 |E: zhouyu@rbs.ruc.edu.cn \\ Xueqing Fan* (corresponding author) \\ Doctoral Student \\ Department of Organization and Human Resources | School of Business \\ No. 59 Zhongguancun Street, Haidian District \\ Renmin University of China, Beijing 100872 China \\ E: skye_fan@ruc.edu.cn \\ Jooyeon Son* \\ Senior Lecturer \\ Department of Management and Marketing | Faculty of Business and Economics \\ Level 10, 198 Berkeley Street \\ The University of Melbourne, Victoria 3010 Australia \\ T: +6139035 7410 | E: jooyeon.son@unimelb.edu.au
}

* The three authors contributed equally to this article.

This is the author manuscript accepted for publication and has undergone full peer review but has not been through the copyediting, typesetting, pagination and proofreading process, which may lead to differences between this version and the Version of Record. Please cite this article as doi: $10.1002 / \mathrm{hrm} .21950$

This article is protected by copyright. All rights reserved. 
This article is protected by copyright. All rights reserved. 
YU ZHOU is an associate professor in the Department of Organization and Human Resources at the School of Business of Renmin University of China. He received his $\mathrm{PhD}$ in human resource management from Renmin University of China. He was a Wertheim research fellow (2013-2014) at Labor \& Work-life Program in Harvard Law School. He specializes his research in organization innovation and people strategy, HRM hybridism in the Chinese context, partnership governance, and sharing mechanism.

XUEQING FAN is a doctoral student of School of Business, Renmin University of China. Her primary research interests are workplace dynamics, such as dynamic performance and over-time changes in employees' well-being, and the influence of organizational human resource management practices and leadership on such dynamics.

JOOYEON SON is a Senior Lecturer in the Human Resource Management Area in the Department of Management and Marketing at the University of Melbourne. She received her $\mathrm{PhD}$ in Human Resource and Industrial Relations from the School of Labor and Employment Relations at University of Illinois, Urbana-Champaign. She conducts research in the areas of gender, leadership, international human resource management, employee well-being, and talent management.

Keywords: high-performance work systems, organizational innovation, employee participation, 
human capital, China

This article is protected by copyright. All rights reserved. 


\title{
How and When Matter: Exploring the Interaction Effects of High-Performance Work Systems, Employee Participation, and Human Capital on Organizational Innovation
}

\begin{abstract}
Existing research on the relationship between high-performance work systems (HPWS) and organizational innovation has paid insufficient attention to the boundary effects of employee participation and human capital. Bridging the human resource management (HRM) and employment relations literature, this study contributes to the contingency view of HRM and China-specific research by investigating how human capital and employee participation, direct voice mechanism and corporate governance participation, jointly moderate the relationship between HPWS and organizational innovation. We test our three-way interaction model using a sample of 108 firms and 1,250 employees in China. The results suggest that HPWS are positively associated with organizational innovation when employees with relatively less human capital are coupled with more direct voice mechanism or less corporate governance participation. In contrast, HPWS are negatively related to organizational innovation when employees possessing greater human capital are coupled with more direct voice mechanism. The theoretical and managerial implications and future research directions are discussed.
\end{abstract}

Keywords: high-performance work systems, organizational innovation, employee participation, human capital, China

This article is protected by copyright. All rights reserved. 
This article is protected by copyright. All rights reserved. 


\title{
How and When Matter: Exploring the Interaction Effects of High-Performance Work Systems, Employee Participation, and Human Capital on Organizational Innovation
}

\begin{abstract}
Modern organizations are increasingly emphasizing and supporting employees' active involvement and participation in the workplace. For example, recent survey results show that $31 \%$ of European employees work in high-involvement organizations, and 67\% of European employees are at least sometimes involved in the process of influencing job-related activities and decisions (European Working Conditions Survey, 2015). Furthermore, in China, more than 90\% of companies implement specific types of employee participation (National Survey of Democratic Management in Enterprises, 2016). The widely adopted high-performance work systems (HPWS), also referred to as high-involvement work systems, provide job decision latitude and group problem-solving opportunities (Li, Wang, van Jaarsveld, Lee, \& Ma, 2017) that unleash employees' potential to contribute to superior organizational performance (Jiang, Lepak, Hu, \& Baer, 2012). In addition to HPWS, most organizations also have diverse employee participation channels, ranging from collective representation through trade unions to individual voice via intranet (Mowbray, Wilkinson, \& Tse, 2015; Wilkinson, Townsend, \& Burgess, 2013). It has been suggested that participation practices, when implemented with HPWS, bring synergy to the organization (Wilkinson \& Fay, 2011; Mowbray et al., 2015). Specifically, these practices are likely to strengthen the effect of HPWS by allowing employees to speak up in different ways. For example, Blasi and colleagues (2016) note that when employee ownership, which enhances
\end{abstract}


employee participation in decision-making and information sharing, is associated with HPWS, employee ownership and HPWS tend to better facilitate organizational performance than when utilized separately. However, we find a gap in the current human resource management (HRM) literature in that researchers have investigated HPWS in isolation from coexisting participative mechanisms (Barry \& Wilkinson, 2016), such as employee participation practices. Therefore, this study aims to examine how, in the context of a variety of employee participation practices, HPWS contribute to organizational innovation.

In particular, we focus on organizational innovation in the Chinese context because innovation has been strongly emphasized as a driving force of economic and social development by the Chinese government. For instance, at the 18th National Congress of the Communist Party of China held in 2012, the "Innovation-driven Development Strategy" was proposed. Moreover, Chinese Premier Li Keqiang called upon "mass entrepreneurship and innovation” at the World Economic Forum conference in 2014 to encourage people's active participation in enhancing innovation. With HPWS and employee participation practices, Chinese companies have achieved remarkable development in innovation by encouraging employee involvement in the innovation process (e.g., Kesting, Song, Qin, \& Krol, 2016; Liu, Gong, Zhou, \& Huang, 2017; Zhang \& Barto, 2010). Although there are numerous studies investigating the impact of HPWS (e.g., Chang, Jia, Takeuchi, \& Cai, 2014; Cooke, Cooper, Bartram, Wang, \& Mei, 2016; Liu et al., 2017) on innovation (e.g., Zhou, Gao, \& Zhao, 2017; Zhou, Hong, \& Liu, 2013) in the Chinese context, it remains unknown how HPWS influences organizational innovation in conjunction 
with employee participation practices specifically in Chinese companies. Thus, using samples from China, the current study aims to gain a better understanding of the combined effects of HPWS and employee participation on organizational innovation among Chinese companies.

Furthermore, although a number of studies in the employment relations literature have investigated the interplay of different participation mechanisms, such as formal and informal participation (e.g., Marchington \& Suter, 2013), high-involvement management practices and trade union representation (e.g., Bryson, Forth, \& Kirby, 2005), and direct and indirect participation (e.g., Gallie, 2013), we find several gaps in the current research. First, while union representation has gained much attention, the effects of other types of participative mechanisms, such as employee representation on the board of directors, are relatively under-researched. Second, although the innovation literature highlights employee participation (e.g., Bashshur \& Oc, 2015; Wang, Zhao, \& Thornhill, 2015), the employment relations literature remains relatively silent on participative mechanisms' influence on organizational innovation. Third, the current literature indicates inconsistency in the interaction effects of HRM and employee participation on organizational performance. For instance, Kim and Kang (2013) find that strategic HR function is positively related to firm performance in the context of strategic union participation. In contrast, Bryson et al. (2005) find no significant relationship between high-involvement management practices and financial performance in unionized workplaces.

To fill the gaps, we propose two distinct forms of employee participation based on (in)directness and the degree of influence on decision-making (e.g., Wilkinson et al., 2013) and 
examine how HPWS along with employee participation affect organizational innovation. Employee participation refers to any type of mechanism, structure, or practice that provides employees with opportunities to express opinions or participate in decision-making within their organizations (Lavelle, Gunnigle, \& McDonnell, 2010). The current paper suggests direct voice mechanism, which refers to suggestion-making practices that build broad open channels for employees to directly express concerns and views, and corporate governance participation, which is conceptualized as decision-making structures that allow employees to participate in corporate governance indirectly through union and nonunion representation as two types of employee participation. Specifically, we argue that direct voice mechanism and corporate governance participation play different roles when complementing the impact of HPWS on organizational innovation. While direct voice mechanism simply broaden the participation avenues by channeling employees' ideas to management, corporate governance participation can further involve employees in strategic decision-making and thus is more influential for gaining resources and management support to implement innovative ideas.

Additionally, it is important to take human capital—defined as the cumulative knowledge, skills, talent, and knowhow of the firm's employees (Somaya, Williamson, \& Lorinkova, 2008) — into consideration when examining the impact of employee participation. A high level of human capital is believed to increase the benefits of employee participation (Glaeser, Ponzetto, \& Shleifer, 2007; Harrison \& Freeman, 2004; Kerr, 2004). Given the conflicting findings in the current literature (e.g., Bryson et al., 2005; Kim \& Kang, 2013), which suggest potential 
contingencies in the interaction effect of HRM and employee participation on organizational outcomes, we contend that investigating human capital along with the association between HPWS and organizational performance under various participative mechanisms will be helpful to address the discrepancy. Consequently, we investigate the three-way interaction effects of human capital, direct voice mechanism and corporate governance participation, and HPWS on organizational innovation. Although prior HRM literature has highlighted the importance of human capital in the functioning of HRM, recent studies have focused primarily on the role of HRM practices but failed to take human capital into account (Wright \& McMahan, 2011). With notable exceptions that investigate human capital as a mediator between HPWS and performance (e.g., Jiang et al., 2012), much still needs to be investigated regarding how employees with different levels of human capital respond to HPWS and employee participation and thereby impact organizational outcomes (Gallie, 2013). In particular, innovation depends heavily on knowledge and expertise as key inputs throughout the creativity generation process (Chang et al., 2014). Therefore, we contend that empirically examining human capital as a contingency provides us with a more comprehensive understanding of the interplay between HPWS and employee participation in their effects on organizational innovation.

The contributions of this study are threefold. First, we extend the employment relations literature by investigating the interaction between HPWS and employee participation and extend the employment relations literature to the innovation domain. Second, we contribute to the contingency view of the HRM literature by focusing on the boundary effects of employee 
participation on the HPWS-innovation relationship. Third, by proposing a three-way interaction effect in the Chinese context, we contribute to the China-specific research on innovation and employee participation. Finally, we enrich the human capital literature by investigating how human capital shapes the interaction effects of HPWS and employee participation on innovation.

\section{THEORY AND HYPOTHESES}

\section{Organizational Innovation and HPWS}

Organizational innovation captures the extent to which novel and useful ideas or solutions to problems are implemented (Mumford, 2011). Hence, innovation generally encompasses two stages: the generation of creative ideas and the implementation of these ideas (Anderson, De Dreu, \& Nijstad, 2014). While idea generation is more dependent on individual knowledge and skills, organizational factors contribute to the implementation of these ideas (Axtell et al., 2000). As Baer (2012) claims, creative ideas are positive predictors of innovation, but successful innovation involves more than just creative ideas. In other words, producing suggestions does not necessarily improve organizational innovation without successful implementation.

HPWS, which generally refers to a set of HR practices designed to enhance employees' skills, commitment, and productivity (Datta, Guthrie, \& Wright, 2005), play an important role in facilitating organizational innovation, because organizational innovation is largely determined by a firm's ability to manage knowledge and motivate employees to engage in the innovation process (Jiang et al., 2012; Smith, Collins, \& Clark, 2005). HPWS benefit innovation by developing employees' knowledge and motivating them to apply knowledge to creative activities 
(Liu et al., 2017). For example, rigorous recruitment and selection are intended to ensure that employees have the knowledge needed to perform creative activities. Extensive training enlarges employees' knowledge base beyond that required for current tasks. Job enrichment encourages employees to gain more domain-relevant knowledge by taking on diverse roles and performing challenging tasks (Lado \& Wilson, 1994). Moreover, emphasis on teamwork and group-based performance pay allows group members with diverse knowledge to collaborate, thereby enhancing knowledge sharing and recombination (Han, Han, \& Brass, 2014). Working on a team also induces employees' intrinsic motivation to find creative solutions at work (Chang et al., 2014). Performance-contingent incentives, internal promotion, and job security under HPWS can elicit extrinsic motivation in employees to invest more effort in creativity (Jiang et al., 2012).

Employee participation also plays a significant role in the efficient functioning of HPWS, as it complements HPWS by facilitating the conversion of creative ideas into output. With participation platforms, employees are more likely to gain approval, support, and resources for creative ideas by speaking up or exerting influence on management. Particularly in China, where public participation is regarded as an important facilitator of innovation by the government, HPWS and employee participation practices are implemented by organizations to stimulate employees' contribution to organizational innovation (e.g., Kesting et al., 2016; Liu et al. 2017; Zhang \& Barto, 2010). Thus, joint consideration of HPWS and employee participation is meaningful and critical, especially in the Chinese context.

\section{Direct Voice Mechanism and Corporate Governance Participation}


In the architecture of employee participation, practices differ greatly in terms of the form and the amount of influence employees can exercise over management (Wilkinson et al., 2013). Specifically, employees can participate directly or indirectly. While direct participation mechanisms allow employees to affect workplace issues without the mediation of representatives, indirect participation mechanisms function through employee representatives, such as unions or employee representation on board of directors (Kim, MacDuffie, \& Pil, 2010). Furthermore, the depth of employees' influence on workplace decisions varies across different participation practices. Some forms of participation simply give employees a channel to voice without truly involving them in decision-making, whereas others provide employees with a more significant say in organizational governance. Given the differences in their (in)directness and degree of influence on decision-making, we identify corporate governance participation and direct voice mechanism as two distinct configurations of employee participation.

Direct voice mechanism is a "direct" participation arrangement that provides opportunities to make suggestions (Wang et al., 2015). It broadens the avenue through which employees can actively express concerns, complaints, opinions, and views that emerge at work to management across the company. In organizations where direct voice mechanism is well established, employees can easily share their opinions directly with management whenever they experience work-related problems or come up with new ideas. With direct voice mechanism, employees can even go above their immediate supervisors to express opinions and grievances openly and independently on various issues (Wilkinson \& Dundon, 2010). In particular, the rapid 
development of the Internet and information technology makes direct voice mechanism much more accessible to employees than in the past. Through direct voice mechanism, organizations are able to pay greater attention to employees' opinions and their multiple perspectives. Thus, employees are more likely to gain the support and resources needed to put their ideas into practice. The meta-analysis conducted by Ng and Feldman (2012) also finds strong support for the resource acquisition effect of employee voice.

On the other hand, corporate governance participation serves as an "indirect" employee participation practice that protects employees' interests by enabling employee representatives to effectively influence decision-making by discussing management affairs, reviewing and approving decisions made by enterprises, monitoring management, and negotiating issues related to employees' well-being (Kleinknecht, 2015; Pohler \& Luchak, 2015). It is noteworthy that although the primary purpose of direct voice mechanism is to provide a mechanism for employees to speak up, it may not have a major impact on decision-making. After employees' suggestions are solicited, it is the management team who decides whether the suggestions can be put into practice (Barry \& Wilkinson, 2016). Generally, individual employees do not have the authority to make direct decisions about how to solve problems and may not be involved in implementing the suggestions that are accepted by management. In contrast, corporate governance participation enables employees to exert a significant influence on strategic decision-making "indirectly" via trade unions, workers' congresses, top management meetings, and employee representation on company boards of directors, etc. Through such formal and even 
legal structures, employees are organized to play a definite, substantive role in workplace decision-making via representatives. They can share ideas on business matters, negotiate the employment conditions under which they work, and oversee organizational management (Kleinknecht, 2015; Pohler \& Luchak, 2015). Engaged in corporate governance participation, employees have more control over the process that leads to outcomes. In other words, employees in an organization where corporate governance participation is well established are able to gain approval, provide support, and seek necessary material, personnel, and financial resources for the translation of innovative ideas into output. Indeed, participation in decision-making is found to facilitate the transformation of creative ideas into innovation (e.g., Bashshur \& Oc, 2015).

However, the combined effects of HPWS and direct voice mechanism/ corporate governance participation on organizational innovation are still contingent upon potential contextual factors. In particular, we focus on the role of human capital in the HPWS, direct voice mechanism/ corporate governance participation, and organizational innovation association because it has been suggested human capital plays an important role in employee participation (Glaeser et al., 2007; Harrison \& Freeman, 2004; Kerr, 2004). For instance, Kerr (2004) indicates that employee participation may provide different levels of competitive advantage because of the differences in workers' ability to participate in the flow of information and decisions. From an innovation perspective, innovation depends heavily on the knowledge and expertise embedded in human capital as key inputs in the creativity process (Hitt, Biermant, Shimizu, \& Kochhar, 2001). Therefore, we investigate the three-way interaction of HPWS, direct 
voice mechanism/ corporate governance participation, and human capital on innovation.

\section{Three-way Interaction of HPWS, Direct Voice Mechanism, and Human Capital}

Human capital, which refers to the cumulative knowledge, skills, talent, and knowhow of employees (Somaya et al., 2008), is often represented by a level of education (De Winne \& Sels, 2010; Jiang et al., 2012). Thus, a low education level, as a proxy for low-level human capital, can be regarded as an indicator of a lack of expertise and skills (Ployhart \& Moliterno, 2011). In general, organizations use different HR configurations to manage the corresponding human resources and thereby match employees' relative status and maximize their potential contribution (Lepak \& Snell, 2002). Consequently, less-educated employees commonly experience fewer opportunities for extensive training and participation in decision-making. However, less-educated employees, compared to those who are highly educated, tend not to propose novel ideas themselves because they lack relevant knowledge or are unwilling to speak up (Nembhard \& Edmondson, 2006). However, less-educated employees can also facilitate the achievement of innovation (Lepak \& Taylor, Tekleab, Marrone, \& Cohen, 2007) if they can develop ability and gain opportunities to voice. In organizations that implement HPWS, these employees are more likely to have opportunities to develop knowledge and skills that enable them to discover job-related problems and generate new ideas. Hence, less-educated employees will be able to and motivated to speak up under HPWS. In this case, we expect HPWS and direct voice mechanism to facilitate innovation when low-human-capital employees are no longer excluded from employee participation. The broadened communication avenue stimulates novel ideas to emerge 
from the bottom up and to be communicated to management. Through direct voice mechanism, less-educated employees are more likely to freely express opinions and concerns that arise at work. Therefore, the perspectives and experiences of employees possessing low levels of human capital will benefit organizations, particularly in terms of innovation. Based on the above argument, we hypothesize the following:

Hypothesis 1: Direct voice mechanism and human capital jointly moderate the relationship between HPWS and organizational innovation such that HPWS will lead to higher innovation when employees with a lower degree of human capital are provided greater direct voice mechanism.

However, we predict that HPWS may limit innovation when direct voice mechanism is exercised in firms with high levels of human capital. Education is also believed to be an indicator of individuals' capacity to recognize valuable information, assimilate it, and put it to use (Obstfeld, 2005). Therefore, for highly educated employees, possessing deep knowledge enables deeper knowledge assimilation. Compared with less-educated coworkers, employees with more human capital are assumed to develop greater proficiency in specific skills and job-specific expertise when they receive extensive training and job enrichment in the organizations where HPWS are implemented (Rauc, Frese, \& Utsch, 2005). These employees are more likely to discover new phenomena, question prevailing norms, and offer suggestions regarding existing or potential problems (Tushman \& Anderson, 1986). Hence, employees who possess more human capital tend to come up with more suggestions than those who have less human capital, ranging 
from shop-floor issues to firm-level matters. Also, it has been proposed that education, as an indicator of human capital, is positively related to creativity (Rogers, 2010).

While idea generation is more closely related to personal and job characteristics, idea implementation is more strongly predicted by group and organizational factors (Axtell et al., 2000). Direct voice mechanism is merely a type of suggestion scheme that channels employees' opinions to management without necessarily engaging them in decision-making, and it is dependent on managers to determine how to address these suggestions (Barry \& Wilkinson, 2016). Because resources in an organization are limited to ensure the implementation of all suggestions, when first proposed, most of these suggestions are often rejected because they are perceived to be inappropriate, unworkable, or risky (Baer, 2012; Janssen, Van de Vliert, \& West, 2004). Given that well-educated employees tend to come up with a wider range of suggestions than their less-educated coworkers, it is very likely that a large proportion of creative ideas will not be adopted without the necessary support. Unlike employees with a low degree of human capital, well-educated proposers usually desire more self-expression and higher-order need fulfillment (Miller and Monge, 1986). They engage in direct voice mechanism with the expectation of obtaining valued outcomes (Salancik \& Pfeffer, 1977). If their voices are heard without being implemented, well-educated workers may conclude that their suggestions are not valued or taken seriously (Godkin, 2015). The failure to transform their ideas may frustrate them, discouraging further idea sharing and, in turn, compromising organizational innovation. Taken together, we hypothesize the following: 
Hypothesis 2: Direct voice mechanism and human capital jointly moderate the relationship between HPWS and organizational innovation such that HPWS will lead to lower innovation when employees with a higher degree of human capital are provided greater direct voice mechanism.

\section{Three-way Interaction of HPWS, Corporate Governance Participation, and Human}

\section{Capital}

Unlike direct voice mechanism, corporate governance participation requires employees to become involved in firm-level affairs and make decisions concerning strategic matters; thus, it sets higher requirements on human capital. For instance, employee representatives should grasp necessary management, accounting, or finance knowledge when they participate in top management meetings. Employees need to not only possess extensive knowledge to understand current problems and make constructive suggestions but also have the ability to determine feasible solutions that do not result in negative consequences for the firm (Glaeser et al., 2007). As a consequence, we predict that less-educated employees are less likely to be considered qualified to participate in corporate governance participation, and in turn, they may harm innovation when exposed to the context in which corporate governance participation is actively employed for the following reasons.

First, knowledge limitations that result from low education may result in erroneous decisions that promote the implementation of unpromising ideas. Kimberly and Evanisko (1981) find that less education is associated with relatively lower problem-solving ability. Despite the 
intention to innovate promising products or services, those possessing low human capital often cannot identify the inevitable defects, which may lead to unintended failures. If errors are introduced by corporate governance participation, it will result in risks that threaten organizational innovation. Second, employees with less human capital may impede innovation by disapproving of the transformation of promising ideas. Compared with highly educated individuals, employees with a lower degree of human capital are less likely to be receptive to novel ideas and changes (Boeker, 1997). When faced with the potential risks inherent to novel ideas, these employees' knowledge deficiency is more likely to keep them from supporting these ideas. Similarly, Harrison and Freeman (2004) argue that if given decision-making power, employees with less human capital may choose a path that is not advantageous for the organization. Based on the logic above, we expect that corporate governance participation might adversely influence organizational innovation when it is broadly open to less-educated employees. Even under HPWS, inadequate cognitive ability due to low education may limit employees' ability to address multiple issues simultaneously (Sanderson, Bruk-Lee, Viswesvaran, Gutierrez, \& Kantrowitz, 2013). When simultaneously faced with union activities, board affairs, or management matters and work tasks, low-human-capital employees may find it challenging to handle any of these issues efficiently.

In contrast, HPWS may promote innovation when less-educated workers are only offered low corporate governance participation. Participating in corporate governance participation costs a great deal of time and energy, particularly for those lacking the competency to perform 
multiple tasks at the same time. If provided with less corporate governance participation, individuals can invest their time and energy in core work activities that directly and immediately contribute to organizational innovation (Janssen et al., 2004). As we argued earlier, HPWS help less-educated employees broaden their skills and motivate them to share knowledge and contribute expertise. Consequently, HPWS will promote organizational innovation by stimulating less-educated employees to discover potential problems in established operative norms and find efficient ways to complete current tasks. Based on the above argument, we hypothesize the following:

Hypothesis 3: Corporate governance participation and human capital jointly moderate the relationship between HPWS and organizational innovation such that HPWS will lead to higher innovation when employees with a lower degree of human capital are provided lower corporate governance participation than when they are provided higher corporate governance participation.

In contrast, we theorize that corporate governance participation engagement by those with higher education (i.e., higher human capital) will be more favorable to organizational innovation than engagement by less-educated employees. By incorporating well-educated employees in organizational decision-making through trade unions, workers' congresses, boards of directors, boards of supervisors, and top management meetings, corporate governance participation creates a platform to enhance knowledge sharing and exchange. Additionally, participation in decision-making is considered one of the most effective approaches to motivating employees to 
perform desirable behaviors (Zhang \& Bartol, 2010). When participating in corporate governance participation, employees' intrinsic motivation to work and willingness to invest in an organization will increase. Well-educated employee representatives are assembled to contribute their expertise to organizational development and problem-solving. Interactions between managers and workers from diverse fields will elicit novel linkages and associations beyond what management can achieve alone (Kilgour, 2006). A diverse body of knowledge and perspectives from management and the workforce integrated through corporate governance participation thus increases the likelihood of discovering innovative solutions to problems.

Furthermore, because creative ideas generated under HPWS may create conflicts and objections, innovation processes can be slowed or even prevented without support from the organization (Axtell et al., 2000; Janssen et al., 2004). Participation in corporate governance participation allows well-educated proposers to gain the social help needed to implement creative ideas (Ng \& Feldman, 2012). This participation not only improves people's understanding of - and thus reduces their resistance to - novel ideas but also aids proposers in gaining the approval and resources needed to put their ideas into practice. Through corporate governance participation, employees influence strategic, administrative, and operating issues (Kleinknecht, 2015; Pohler \& Luchak, 2015). Therefore, corporate governance participation can boost the transformation of new ideas and enhance innovation by exerting greater impact on management and mobilizing organizational resources. Similarly, several studies have confirmed that proposed ideas are more likely to be implemented if employees are allowed to participate in decision 
making (Bashshur \& Oc, 2015). Consistent with the above arguments, we predict the following:

H4: Corporate governance participation and human capital jointly moderate the relationship between HPWS and organizational innovation such that HPWS will lead to greater innovation when employees with a higher degree of human capital are provided with higher corporate governance participation.

The conceptual framework of this paper is shown in Figure 1.

Insert Figure 1 about here

\section{METHODS}

\section{Sample and Data Collection Procedures}

The data come from firms from various industries in the People's Republic of China. In striving toward an innovation-based economy, the Chinese government places great emphasis on innovation and encourages all citizens to become involved. Following a multisource procedure (Huselid \& Becker, 2000) and to reduce common method bias, we collected information from various respondents in each organization. Specifically, the CEO provided basic information about the firm, such as industry, firm age, and ownership. Senior HR managers completed a survey including questions that capture HPWS, corporate governance participation, direct voice mechanism, and firm size. The product operations manager was invited to provide information on organizational innovation. Employees from the product operations department were randomly invited to provide information on their education. 
A survey package with an invitation to participate in this study was sent to the HR manager of each organization. Each package contained a cover letter explaining the purpose of the study and ensuring the confidential treatment of every survey response, a set of precoded questionnaires, and detailed instructions for survey administration. We translated all questionnaires into Chinese following the back-translation procedure recommended by Brislin (1980). The HR managers passed the questionnaires along to CEOs, product operation managers, and employees in the product operation department. Completed questionnaires were then either submitted to the research assistants on site or mailed directly to the researchers.

A total of 200 CEOs, 200 HR managers, 200 product operation managers, and 2,500 employees were invited to participate in this study. We received responses from 125 CEOs, 144 HR managers, 132 product operation managers, and 1,977 employees, leading to a response rate of $62.5 \%$ for the CEOs, $72 \%$ for the HR managers, $66 \%$ for product operation managers, and $79.1 \%$ for employees. After cleaning and matching the questionnaires, we obtained usable responses from $108 \mathrm{CEOs,} 108 \mathrm{HR}$ managers, 108 product operation managers, and 1,250 employees. In the final sample, $65.7 \%$ of firms were from the manufacturing industry and $29.6 \%$ were from the service industry. The average firm age is 12.88 years $(\mathrm{SD}=7.86)$. Among the 108 firms, 9.3\% were state-owned enterprises, $6.5 \%$ joint venture enterprises, $56.5 \%$ private enterprises, $5.6 \%$ foreign-owned enterprises, and $22.1 \%$ others. In total, $13.9 \%$ of the final samples were listed companies. The 108 responding firms reported an average firm size by an employee scale of 5.45 (with a natural logarithm function transformation; SD = 1.27). An 
average of 11 employees responded within each organization, with a range of 5 to 12 employees. According to the education information reported, $69.9 \%$ of employees had achieved a college degree or above.

\section{Measures}

Direct voice mechanism and corporate governance participation. The concept of employee participation covers a wide variety of practices (Mowbray et al., 2015). Therefore, diverse measures are used to conceptualize different forms of participation, and there are no widely accepted scales. In addition, the majority of research is conducted in Western countries. Because the forms of employee participation in countries differ greatly (Kaufman \& Taras, 2010), the practices used in Western countries may not apply to Chinese companies. For example, while joint consultative committee is popular in the United Kingdom and works council is mandatory in Germany, workers' congress is common in China. Thus, the existing measures used in the Western context may not be suitable for this research. Accordingly, we constructed our own measures for direct voice mechanism and corporate governance participation through the following procedure (for a similar approach, see Collins \& Smith, 2006).

First, item generation was based on a thorough review of the literature and semistructured interviews. In particular, we searched the existing literature on employee participation in China. Diverse employee participation practices are common in different industries for different purposes, such as saving costs, improving customer satisfaction, and enhancing innovation (e.g., Jaca, Viles, Mateo, \& Santos, 2012; Marín-García \& Bonavía, 2015; Marín-García \& Poveda, 
2010; Scherrer-Rathje, Boyle, \& Deflorin, 2009). Particularly for innovation, which requires the interaction of diverse perspectives and assumptions (Anderson et al., 2014), employee participation is important for channeling various ideas to the management or involving different opinions in the strategic decision-making process. By conducting the literature review, we were able to create an initial item pool with practices that stimulate employees' participation via suggestion-making or decision-making; the pool included eight and seven items that represented direct voice mechanism and corporate governance participation, respectively. Then, we interviewed $10 \mathrm{HR}$ managers from different Chinese companies in diverse industries and asked about the commonly used employee participation mechanisms in their organizations. Each HR manager was asked to answer two questions: "What are the formal structures currently implemented in your company that allow employee representatives to participate in corporate governance?" and "What are the approaches currently implemented in your company that facilitate suggestion-making directly to the management?". The HR managers' answers showed that different companies adopted similar corporate governance participation practices, and they were all included in our initial item pool. The direct voice mechanism mentioned by the HR managers also closely matched those approaches we identified in the literature and included in the initial item pool. We removed items from the initial pool that were not mentioned any of the HR managers, such as collective bargaining for wages and democratic evaluation. According to further follow-up interviews with the HR managers, these deleted items were not in use or open to employees. This process resulted in six direct voice mechanism items and four corporate 
governance participation items.

To conduct a content evaluation, we then recruited five doctoral students majoring in HRM and employment relations who were unaware of the hypotheses. These students received a survey with definitions of direct voice mechanism and corporate governance participation, followed by the 10 items. They were asked to sort these items into three categories ("direct voice mechanism", "corporate governance participation", and "others") based on the extent to which they believed each item corresponded with the definition provided. Sorting the items to "others" indicated a low content validity and thus was deleted. Through this content evaluation process, we narrowed down the pool to five items for direct voice mechanism and four items for corporate governance participation.

Next, to quantitatively validate the two scales, we administered a survey with the nine items to perform exploratory factor analysis (EFA). We asked respondents to rate the extent to which each practice accorded with the situation in their organization $(1=$ not at all, $5=$ very $m u c h)$. The sample consisted of 49 managers from various organizations in China, $49 \%$ were male, $85.7 \%$ were below 35 years old, and mean work experience was 8.45 years $(\mathrm{SD}=3.48)$. All the respondents held bachelor's degree or above. The results of the EFA supported the two-factor model, with items loaded on theoretically relevant factors. All factor loadings were greater than .07 except one from the direct voice mechanism scale, which had a factor loading less than .06 and thus was deleted. The final scales for direct voice mechanism $(\alpha=.92)$ and corporate governance participation $(\alpha=.89)$ each included 4 items (see Table 1 for the specific 
items).

Insert Table 1 about here

To provide further evidence supporting our developed measures, we then examined the correlations of direct voice mechanism and corporate governance participation with turnover intention and procedural justice. In line with previous research, we expected that both direct voice mechanism and corporate governance participation would be positively correlated with procedural justice and negatively correlated with turnover intention (Bashshur \& Oc, 2015). We collected data from an executive MBA class, where the respondents are top managers from different Chinese companies. The survey included corporate governance participation, direct voice mechanism, HPWS (11 items used in this study, see items later), turnover intention (5 items [Wayne, Shore, \& Liden, 1997]), and procedural justice (7 items [Colquitt, 2001]). The final usable sample consisted of 100 managers, all with a bachelor's degree or above. Of the respondents, 66 were male, $85.7 \%$ were below 35 years of age, and the mean work experience was 9.78 years $(\mathrm{SD}=4.10)$. As expected, procedural justice was positively correlated with direct voice mechanism $(r=.56, p<.01)$ and corporate governance participation $(r=.46, p<.01)$, and turnover intention was negatively correlated with direct voice mechanism $(r=-.31, p<.01)$ and corporate governance participation $(r=-.25, p<.01)$.

Then, the two newly validated scales were used to measure direct voice mechanism and corporate governance participation. Senior HR managers from 108 firms were asked about the implementation of direct voice mechanism and corporate governance participation. We used a 
Likert scale ranging from 1 (strongly disagree) to 5 (strongly agree). For this sample, the Cronbach's alpha reliability coefficients for direct voice mechanism and corporate governance participation were .89 and .88 , respectively.

High-performance work systems (HPWS). We constructed a measure of HPWS by synthesizing the prominent scales used in different studies in both the Western and Chinese contexts (i.e., Xiao \& Björkman, 2006; Zhou et al., 2013). A total of 11 items were rated from 1 (strongly disagree) to 5 (strongly agree), including job enrichment, self-management team, value-based recruitment and selection, extensive training, team-based performance and incentives, egalitarianism, internal promotion, information sharing, job security, profit-sharing plan, and employee stock ownership $(\alpha=.83)$. To provide additional evidence of the construct validity, we followed the procedures adopted by Collins and Smith (2006). More specifically, we utilized the same sample used to validate the direct voice mechanism and corporate governance participation measures (100 managers from different Chinese companies) to investigate the association between the HPWS index and employee turnover intention, an indicator of a long-term relationship (Collins \& Smith, 2006). When a company carries out HPWS, employees were expected to build mutual commitment with employer and thus hold lower turnover intention than employees working in a company with control-based HRM practices. As expected, we found that our index of HPWS was negatively correlated with turnover intention $(r=-.47, p$ $<.01)$.

Human capital. Multiple measures have been used to gauge human capital, such as 
education, experience, and tenure (Nyberg, Moliterno, Hale Jr, \& Lepak, 2014). In line with previous works (De Winne \& Sels, 2010; Haber \& Reichel, 2007; Jiang et al. 2012; Smith et al., 2005), we used employees' educational level as a proxy for their human capital, which represents the preexisting stock of ability, knowledge, and skills valuable to organizational innovation (Ployhart \& Moliterno, 2011). Formal education is assumed to be a good indicator of employees' knowledge stock (Smith et al., 2005). It is true that education does not measure the knowledge and skills acquired during employees' careers. However, several studies show that highly educated employees participate more in training and engage more in lifelong learning than less-educated employees (Rauch et al., 2005). As indicated by D'Aveni (1996), the value of employees' education persists throughout their careers. Hence, we theorize that education offers a contextual condition for employee participation. We assume that the initial gap in competences and knowledge between highly educated and less-educated employees tends to enlarge during their careers and thus exert greater influence on organizational innovation. On average, 11 employees from each product operation department were randomly selected to report their education. We asked respondents to choose their education level from "less than high school", “technical secondary school or high school”, “two-year college”, "bachelor's degree”, "master's degree" and "doctoral degree", and these were coded from "1" to "6", respectively. Firm-level human capital scores were created by averaging the education scores of all surveyed agents within a firm $(\operatorname{ICC}[1]=.49, \operatorname{ICC}[2]=.92, r w g=.83$, and $F[107,1142]=12.28, p<.01)$. All were within the acceptable range of values indicated in the literature (Bliese, 2000). 
Organizational innovation. We measured organizational innovation as the percentage of new-product (including new goods and services) profits over total profits (see Guan \& Yam, 2015 for a similar approach). A variety of methods have been used to measure organizational innovation, such as R\&D expenditure, patents, or the number of marketed innovations (e.g., Jung, Chow, \& Wu, 2003; Qian, Cao, \& Takeuchi, 2013). However, these approaches have limitations (see Negassi, 2004): R\&D expenditure is merely an input to innovation; organizations may not seek a patent for every innovation; the innovative content and commercial value of different innovations differ a great deal. Instead, the measure used in the current paper both reflects the commercial value of innovation and provides a more appropriate way to assess the influence of non-R\&D innovation inputs. We believe this approach is more appropriate for operationalizing organizational innovation. In addition, our discussions with the surveyed companies' product managers indicated that it was appropriate to use this measure to capture the surveyed companies' innovation levels.

Control variables. We controlled for characteristics that may influence the dependent variable, including firm size (Damanpour, 1996), industry (Datta et al., 2005), and R\&D input (Scherer, 1965). We measured firm size as a firm's total number of employees (Ahuja, 2000) and $\mathrm{R} \& \mathrm{D}$ input as the proportion of research and development expenditures on sales turnover. Industries (manufacturing, service, and others) in the sample were coded into two dummy variables.

\section{Data Analysis}

This article is protected by copyright. All rights reserved. 
Hierarchical regression analysis was used to test the hypotheses. To avoid multicollinearity between the predictors and the interaction items and to enhance the interpretation of the main effects, we standardized all variables involved in the interactions (Aiken \& West, 1991). A simple slope test was used to examine the three-way interaction.

\section{RESULTS}

Table 2 shows the descriptive statistics (including means and standard deviations of all variables), correlations between every pair of variables, and Cronbach's alpha. The results of hypothesis testing using hierarchical regression analyses are summarized in Table 3.

As shown in Model 2 of Table 3, we found a negative but non-significant relationship between HPWS and organizational innovation. Given that most research suggests a positive relationship between HPWS and organizational performance, the finding in our paper challenges the universal contribution of HPWS. Similarly, the study by López-Cabrales and colleagues (2009) found that neither knowledge-based nor collaborative HR practices directly affected innovative activity. Zatzick and Iverson (2006) also found no significant relationship between high-involvement work practices and productivity. These findings indicate that there are boundary conditions that influence the functioning of HPWS, as claimed in our argument.

Insert Tables $2 \& 3$ about here

Hypotheses 1 and 2 predicted that direct voice mechanism and human capital jointly moderate the relationship between HPWS and organizational innovation. As predicted, the results in Model 4 of Table 3 showed that the three-way interaction term HPWS $\times$ direct voice 
mechanism $\times$ human capital was significantly related to organizational innovation $\left({ }^{2}=-7.61, p\right.$ $<.05)$.

To demonstrate the interaction effect, we plotted the interactive relationship in Figure $2 \mathrm{a}$ and Figure 2b. In Figure 2a, the simple slope of the regression line indicates that HPWS were significantly and positively associated with organizational innovation under the condition of high direct voice mechanism and low human capital $\left({ }^{2}=11.03, p<.05\right)$, and this relationship was nonsignificant under the condition of low direct voice mechanism and low human capital $\left({ }^{2}=\right.$ -5.46, n.s.). Thus, Hypothesis 1 was supported, suggesting that HPWS will lead to higher organizational innovation when employees with less human capital are provided high direct voice mechanism. Figure $2 \mathrm{~b}$ indicates that HPWS were negatively related to organizational innovation when both direct voice mechanism and human capital were high $\left({ }^{2}=-13.20, p<.05\right)$. Additionally, Hypothesis 2 was supported, which predicted a negative relationship between HPWS and organizational innovation when well-educated employees were provided high direct voice mechanism.

Insert Figure $2 \mathrm{a} \& 2 \mathrm{~b}$ about here

Hypotheses 3 and 4 proposed that corporate governance participation and human capital jointly moderate the relationship between HPWS and organizational innovation. The results of Model 4 in Table 3 showed that the three-way multiplicative interaction term HPWS $\times$ corporate governance participation $\times$ human capital was a significant predictor of organizational innovation $\left({ }^{2}=9.50, p<.01\right)$. 
Figure 3a shows that the relationship between HPWS and organizational innovation was positive and marginally significant under the condition of low corporate governance participation and low human capital $\left({ }^{2}=11.46, p<.10\right)$ but not under the condition of high corporate governance participation and low human capital $\left({ }^{2}=-5.89\right.$, n.s. $)$. These results supported Hypothesis 3 that HPWS can lead to higher organizational innovation when employees with a low degree of human capital are provided lower corporate governance participation than when they are provided higher corporate governance participation. The simple slope $\left({ }^{2}=4.08, n . s.\right)$ of the regression line in Figure $3 \mathrm{~b}$ does not fit our prediction that HPWS lead to high organizational innovation under the condition of high corporate governance participation and high human capital. Thus, Hypothesis 4 was not supported. However, Figure $3 \mathrm{~b}$ shows that the relationship between HPWS and organizational innovation was significantly negative under the condition of low corporate governance participation and high human capital $\left({ }^{2}=-16.55, p<.05\right)$. This finding implies that although HPWS will not significantly enhance firm innovation when well-educated employees are provided high corporate governance participation, it will impair innovation when these employees are provided low corporate governance participation.

Insert Figures $3 \mathrm{a} \& 3 \mathrm{~b}$ about here

\section{DISCUSSION}

In this study, we investigated the three-way interaction effects of HPWS, direct voice mechanism and corporate governance participation, and human capital on organizational 
innovation. We found that HPWS resulted in different innovation outcomes when employees who possessed distinct degrees of human capital were involved in employee participation (i.e., direct voice mechanism and corporate governance participation). Specifically, for firms with lower levels of employee human capital (i.e., lower education levels), HPWS combined with high direct voice mechanism or low corporate governance participation were positively related to organizational innovation. In contrast, for firms with higher levels of employee human capital (i.e., higher education levels), HPWS together with high direct voice mechanism or low corporate governance participation were negatively related to organizational innovation.

\section{Theoretical Implications}

The findings in the current study make several theoretical contributions. First, this study enriches the employment relations literature by suggesting that HPWS integrate with employee participation to influence organizational innovation. Specifically, we identify direct voice mechanism and corporate governance participation as two distinct employee participation configurations that provide direct approaches for making suggestions and indirect avenues for participating in strategic decision-making, respectively. With direct voice mechanism or corporate governance participation, employees have better access to organizational support and resources, which strengthens HPWS's positive effect on organizational innovation. Although employee involvement and participation are considered important to firm innovation (Bashshur \& Oc, 2015), the association between various participation arrangements and innovation has yet to be well studied in the employment relations literature. By exploring the interaction effects of 
HPWS and direct voice mechanism/corporate governance participation on innovation, we extend the employment relations literature to the innovation domain. Moreover, we also contribute by introducing human capital as a contingency to address the inconsistent findings (e.g., Bryson et al., 2005; Kim \& Kang, 2013) ${ }^{2}$ about the joint effect of HPWS and employment participation on organizational performance. As Timming (2015) asserts, a wider research agenda for employee participation is to compare the contributions of employees with distinct human capital. Therefore, this paper enriches the employment relations literature by shedding light on human capital's role in the functioning of employee participation.

Second, our research has several implications for the HRM literature. Although a growing body of studies investigates the association between HPWS and innovation, the contingent factors for their association have gained insufficient attention (Seeck \& Diehl, 2017). It is asserted that adopting a contingency approach to understand when HR systems function more or less effectively is a fruitful direction (Li et al., 2017). HPWS do not exist alone; they coexist with other employee-related management practices within an organization. Aligning HPWS with other practices, such as employee participation mechanisms, is likely to generate synergistic effects. Therefore, this paper yields new insights into the contingency view of HRM by highlighting how the joint consideration of HRM and employee participation can advance our understanding of the effects of HR systems on organizational outcomes. Moreover, our findings reveal the potential dark side of HPWS, which is consistent with the notion that HPWS may not benefit organizations universally. Wright and Boswell (2002, p. 269) note that "(We) often hear of

\footnotetext{
${ }^{2}$ For a detailed comparison of the studies, please refer to Appendix.
} 
organizations that attempted to copy an HR practice or set of practices from a successful organization, only to find that the copied practices did not result in the same beneficial outcomes." Indeed, the findings of Andreeva and colleagues (2017), López-Cabrales et al. (2009), and Zatzick and Iverson (2006) do not support the "best practice" assertion. In the current literature, the negative influences of HPWS are understudied, and it is unclear what constrains HPWS's effectiveness (Chen, Jiang, Tang, \& Cooke, 2018). From the contingency perspective, our findings suggest a double-edged effect of HPWS on innovation that is dependent on organization-specific contingencies (i.e., employee participation practices and human capital). When high direct voice mechanism or low corporate governance participation is implemented in firms with a high degree of human capital, HPWS become negatively associated with organizational innovation. Thus, we extend the current literature by exploring the potential detrimental effects of HPWS as well as the boundary conditions for HPWS's effective functioning.

Additionally, the current study contributes to the China-specific innovation and employee participation research. To boost economic growth and cope with worldwide competition, the Chinese government has been emphasizing innovation and considers it to be the driving force behind the recent economic development in China. To support the innovation-driven development strategy, the Chinese government proposes “mass entrepreneurship and innovation”, thereby encouraging public participation in the innovation process. According to the Ministry of Science and Technology of China, over 2500 business incubators and accelerators, 11 
national-level indigenous innovation demonstration districts and 146 national high-tech districts have been built (Xing, Liu, \& Cooper, 2018). To stimulate innovation, an increasing proportion of Chinese companies are adopting HPWS to manage human resources and involving employees in the innovation process through various participation avenues (Cooke, 2013; Kesting et al., 2016; Zhang \& Barto, 2010). Thus, we believe that the Chinese context represents a unique setting for investigating employee participation and innovation. Indeed, the Chinese context has attracted burgeoning research interest (Cooke, Xie, \& Duan, 2016). However, employee participation effects in China remain to be questioned (Cooke et al., 2016). Especially since the Chinese government has been paying a considerable amount of attention to utilizing employee participation to boost innovation, it is crucial and valuable to explore how employee participation influences organizational innovation in Chinese companies. Fishkin and colleagues (2010), as well as Kesting and colleagues (2016), indicate that participation can be very effective in China. Consistently, our findings demonstrate that employee participation can contribute to innovation by facilitating the implementation of creative ideas. Even with direct voice mechanism, where managers play a determinant role in deciding how to handle suggestions, innovation can be enhanced when HPWS and an appropriate level of human capital are present. By considering multiple types of participatory mechanisms, we advance the understanding of the impact of employee participation on innovation in the Chinese context. Furthermore, despite the accumulated studies on the HPWS-innovation linkage in the Chinese context, HPWS have always been investigated in isolation from coexisting participation mechanisms. This is an 
oversight because Chinese organizations are implementing multiple employee participation mechanisms along with HPWS, and these practices may generate a synergistic effect on innovation (Wilkinson \& Fay, 2011; Mowbray et al., 2015). In response to the calls for more contextualized studies by HRM and management scholars (e.g., Cooke, 2018; Jackson, Schuler \& Jiang, 2014), this paper enriches the current literature by examining how HPWS, integrated with direct voice mechanism and corporate governance participation, benefit Chinese companies in achieving superior innovative performance.

Finally, our findings also enrich the literature on human capital. Our findings suggest that employee participation is favorable to firm innovation only if it corresponds to an organization's human capital stock, consistent with Lepak and Snell's (2002) claim that differentiated modes of employment should be associated with human capital variations. HRM studies have long focused only on HR practices, without taking human capital — through which these practices ultimately exert an impact - into consideration. HRM researchers call for more attention to the resources that provide a competitive advantage instead of the tools used to build those resources (Wright \& McMahan, 2011). In response to this call for research, our study examines the influence of HPWS on organizational innovation at different degrees of human capital. Human capital, which is considered the knowledge, skills, and abilities that can be developed by HPWS, has been primarily understood to influence the association between HPWS and consequences (e.g., Jiang et al., 2012; Jiang, Takeuchi, \& Lepak, 2013). In contrast, we use education-employees’ preexisting knowledge stock — as a proxy for human capital and examine its moderating effects. 
As Becker (1964) suggests, both education and on-the-job training serve as investments in human capital. However, because skills and knowledge remain relatively stable once acquired, employees' existing and potential human capital are already considered during the recruiting and selection process; thus, once they are hired, employees' human capital may not change profoundly even after training (Wright, Coff, \& Moliterno, 2014). Given that human capital differences are related to inconsistencies in employees' reactions to employee participation, a preexisting stock of human capital can act as a contextual condition for its functioning, particularly for cross-sectional observations.

\section{Managerial Implications}

This study also offers several managerial implications for firms that strive to promote innovation. First, our findings imply that employee participation approaches may complement HPWS in the innovation process. Therefore, beyond implementing HPWS, managers need to initiate more employee participation to mobilize knowledge flows from the bottom-up and thereby enhance the utilization of diverse expertise. On one hand, firms need to take advantage of technological developments to promote direct voice mechanism and reap the benefits of an actively engaged workforce. On the other hand, firms should exercise corporate governance participation to expand employees' involvement in decision-making, especially those who are well educated.

Second, this research demonstrates that organizations should take human capital into account when employing HPWS and employee participation. Despite the potential benefits, 
HPWS and employee participation may harm organizational innovation if they do not correspond to a firm's human capital level. Our findings suggest that while corporate governance participation is more suitable for employees who possess more human capital, direct voice mechanism should be applied in organizations with less human capital. Consequently, firms need to not only incorporate employees in employee participation but also differentiate the implementation according to employees' stock of knowledge and ability.

\section{Limitations and Directions for Future Research}

We acknowledge several limitations in this study. First, although multisource data collection can reduce the likelihood that the findings are influenced by common method bias and therefore provide high confidence in the validity of the results, the data were collected at the same point in time. Because of its cross-sectional research design, this study cannot firmly establish causality. However, one of the purposes of this study is to explore the implementation of HPWS in the context of a preexisting stock of human capital. Given the variability in human capital after on-the-job training, we believe that a cross-sectional design is acceptable for investigating the moderating effect of human capital. Nevertheless, we strongly recommend that future studies use a longitudinal design to test the causal order proposed in our model.

Second, we measured human capital by aggregating the randomly selected employees' education level in each firm, with an assumption that the selected employees were representative of the workforce in an organization. Similarly, Smith et al. (2005) studied existing knowledge and knowledge creation capability and operationalized knowledge workers' education level by 
averaging respondents' years of education from the same firm to arrive at organizational scores. However, we acknowledge that our approach can also be considered a relatively rough way to measure an organization's human capital. For example, human capital has been measured in different ways, using established scales (e.g., Subramaniam \& Youndt, 2005; Youndt, Subramaniam, \& Snell, 2004) or proxies, such as the percentage of highly educated employees who have a bachelor's degree or above (De Winne, \& Sels, 2010). Therefore, we suggest that future studies use other methods to conceptualize human capital and examine its contingent effect.

Third, we acknowledge that HPWS and direct voice mechanism may overlap to some extent. As shown in Table 1, HPWS and direct voice mechanism are moderately correlated $(r=.63)$. Despite this moderate correlation, we believe that direct voice mechanism can play a different role than HPWS and is essential to organizational innovation. The direct participation of a broad body of employees plays a critical role in incremental innovation. Direct voice mechanism enables individual employees to enhance productivity and quality, reduce production time and cost, and improve customer satisfaction with no need for the allocation of significant resources (Marín-García \& Poveda, 2010). With direct voice mechanism, employees are allowed to speak up about a broad variety of issues rather than raise only task-related problems (Wilkinson \& Dundon, 2010). In particular, the development of information and communication technologies enables individuals to voice their ideas more openly and efficiently. Employees can directly bypass their immediate supervisors to express views and grievances about issues including but 
not limited to job-related problems (Wilkinson \& Dundon, 2010). Individuals' opinions and ideas can be delivered and shared immediately across all departments and hierarchies in an organization. Especially in China, the government's call for all people's engagement in innovation makes direct voice mechanism especially important, given its role in stimulating and communicating employees' voice. In this case, direct voice mechanism can function as an independent form of employee participation.

Finally, we propose an avenue for future research to investigate other boundary conditions besides human capital that may mitigate or enhance the effectiveness of employee participation practices in Chinese companies. This is derived from the interviews we conducted with $10 \mathrm{HR}$ managers, from whom we were able to gather some interesting information in line with our findings. Although most of the managers indicated that employee participation was beneficial, two implied that their participation arrangements "exist in name only" because "employees seem to believe that their voice will not be heard or processed". One HR manager explained that the management does try to solve some of the problems, but most of the suggestions are ignored because of the constrained budget, infeasibility, or possible conflicts of interest. As our finding suggests, HPWS combined with direct voice mechanism may not benefit organizational innovation if innovative ideas cannot be implemented, especially for companies with a high level of human capital. Another HR manager indicated that making direct suggestions is not suitable for all employees. Specifically, this manager said, "I think some of the employees want to participate in decision-making in a more influential way rather than giving simple suggestions." 
This observation further confirms our assertion that implementing differentiated participation mechanisms based on employees' different levels of human capital is important to stimulate innovation. Furthermore, throughout the interview process, we found that other factors, such as managers' attitudes toward employee suggestions, may be important determinants of the employee participation outcome. Thus, we recommend future studies to further examine these factors' impact on the link between employee participation and innovation in Chinese companies.

\section{Conclusion}

From a contingency perspective, we provide new insights into the understanding of when HPWS can facilitate or inhibit organizational innovation. The results highlight that HPWS, employee participation (i.e., direct voice mechanism and corporate governance participation), and human capital jointly impact the innovation process. We hope that our findings will stimulate more research on the contingencies surrounding HPWS and provide useful guidance for managers who seek to increase organizational innovation. 


\section{REFERENCES}

Ahuja, G. (2000). Collaboration networks, structural holes, and innovation: A longitudinal study. Administrative Science Quarterly, 45, 425-455.

Aiken, L. S., \& West, S. G. (1991). Multiple regression: Testing and interpreting interactions. Newbury Park, CA: Sage.

Andreeva, T., Vanhala, M., Sergeeva, A., Ritala, P., \& Kianto, A. (2017). When the fit between HR practices backfires: Exploring the interaction effects between rewards for and appraisal of knowledge behaviours on innovation. Human Resource Management Journal, 27(2), 209-227.

Anderson, N., Poto nik, K., \& Zhou, J. (2014). Innovation and creativity in organizations a state-of-the-science review, prospective commentary, and guiding framework. Journal of Management, 40, 1297-1333.

Axtell, C. M., Holman, D. J., Unsworth, K. L., Wall, T. D., Waterson, P. E., \& Harrington, E. (2000). Shopfloor innovation: facilitating the suggestion and implementation of ideas. Journal of Occupational and Organizational Psychology, 73, 265-285.

Baer, M. (2012). Putting creativity to work: The implementation of creative ideas in organizations. Academy of Management Journal, 55, 1102-1119.

Barry, M., \& Wilkinson, A. (2016). Pro-social or pro-management? A critique of the conception of employee voice as a pro-social behaviour within organizational behaviour. British Journal of Industrial Relations, 54, 261-284.

Bashshur, M. R., \& Oc, B. (2015). When voice matters: a multilevel review of the impact of voice in organizations. Journal of Management, 41, 1530-1554.

This article is protected by copyright. All rights reserved. 
Becker, G. S. (1964). Human capital: A theoretical and empirical analysis, with special reference to education. Chicago: University of Chicago Press.

Blasi, J., Freeman, R., \& Kruse, D. (2016). Do broad-based employee ownership, profit sharing and stock options help the best firms do even better? British Journal of Industrial Relations, 54, 55-82.

Bliese, P. D. (2000). Within-group agreement, non-independence, and reliability: Implications for data aggregation and analysis. In: Klein, K. J., \& Kozlowski, S. W. (Eds). Multilevel theory, research, and methods in organizations: Foundations, extensions, and new directions. San Francisco, CA, US: Jossey-Bass.

Boeker, W. (1997). Executive migration and strategic change: The effect of top manager movement on product-market entry. Administrative Science Quarterly, 42, 213-236.

Brislin, R. W. (1980). Translation and content analysis of oral and written material. In H. C. Triandis \& J. W. Berry (Eds.), Handbook of Cross-cultural Psychology. Boston, MA: Allyn \& Bacon.

Bryson, A., Forth, J., \& Kirby, S. (2005). High-involvement management practices, trade union representation and workplace performance in Britain. Scottish Journal of Political Economy, 52, 451-491.

Chang, S., Jia, L., Takeuchi, R., \& Cai, Y. (2014). Do high-commitment work systems affect creativity? A multilevel combinational approach to employee creativity. Journal of Applied Psychology, 99, 665-680.

Chen, Y., Jiang, Y. J., Tang, G., \& Cooke, F. L. (2018). High-commitment work systems and middle managers' innovative behavior in the Chinese context: The moderating role of 
work - life conflicts and work climate. Human Resource Management. 57(5), 13171334

Collins, C. J., \& Smith, K. G. (2006). Knowledge exchange and combination: The role of human resource practices in the performance of high-technology firms. Academy of Management Journal, 49, 544-560.

Colquitt, J. A. (2001). On the dimensionality of organizational justice: a construct validation of a measure. Journal of Applied psychology, 86, 386-400.

Cooke, F. L. (2013). Human resource management in China: New trends and practices. Routledge.

Cooke, F. L. (2018). Concepts, contexts, and mindsets: Putting human resource management research in perspectives. Human Resource Management Journal, 28, 1-13.

Cooke, F. L., Cooper, B., Bartram, T., Wang, J., \& Mei, H. (2016). Mapping the relationships between high-performance work systems, employee resilience and engagement: a study of the banking industry in China. The International Journal of Human Resource Management, 1-22.

Cooke, F. L., Xie, Y., \& Duan, H. (2016). Workers' grievances and resolution mechanisms in Chinese manufacturing firms: key characteristics and the influence of contextual factors. The International Journal of Human Resource Management, 27(18), 2119-2141.

Damanpour, F. (1996). Organizational complexity and innovation: developing and testing multiple contingency models. Management Science, 42, 693-716.

Datta, D. K., Guthrie, J. P., \& Wright, P. M. (2005). Human resource management and labor productivity: does industry matter? Academy of Management Journal, 48, 135-145. 
D'Aveni, R. A. (1996). A multiple-constituency, status-based approach to interorganizational mobility of faculty and input-output competition among top business schools. Organization Science, 7, 166-189.

De Winne, S., \& Sels, L. (2010). Interrelationships between human capital, HRM and innovation in Belgian start-ups aiming at an innovation strategy. The International Journal of Human Resource Management, 21, 1863-1883.

European Foundation for the Improvement of Living and Working Conditions. (2015). First Findings: Sixth European Working Conditions Survey: Résumé. Publications Office.

Fishkin, J. S., He, B., Luskin, R. C., \& Siu, A. (2010). Deliberative democracy in an unlikely place: Deliberative polling in China. British Journal of Political Science, 40(2), 435-448.

Gallie, D. (2013). Direct participation and the quality of work. Human Relations, 66, 453-473.

Glaeser, E. L., Ponzetto, G. A. M., \& Shleifer, A. (2007). Why does democracy need education? Journal of Economic Growth, 12, 77-99.

Godkin, L. (2015). Mid-management, employee engagement, and the generation of reliable sustainable corporate social responsibility. Journal of Business Ethics, 130, 15-28.

Guan, J., \& Yam, R. C. (2015). Effects of government financial incentives on firms' innovation performance in China: Evidences from Beijing in the 1990s. Research Policy, 44, 273-282.

Haber, S., \& Reichel, A. (2007). The cumulative nature of the entrepreneurial process: The contribution of human capital, planning and environment resources to small venture 
performance. Journal of Business Venturing, 22, 119-145.

Han, J., Han, J., \& Brass, D. J. (2014). Human capital diversity in the creation of social capital for team creativity. Journal of Organizational Behavior, 35, 54-71.

Harrison, J. S., \& Freeman, R. E. (2004). Special Topic: Democracy in and Around Organizations Is organizational democracy worth the effort? Academy of Management Executive, 18(3), 49-53.

Hitt, M. A., Bierman, L., Shimizu, K., \& Kochhar, R. (2001). Direct and moderating effects of human capital on strategy and performance in professional service firms: A resource-based perspective. Academy of Management Journal, 44, 13-28.

Huselid, M. A., \& Becker, B. E. (2000). Comment on "Measurement error in research on human resources and firm performance: How much error is there and how does it influence effectsize estimates?" by Gerhart, Wright, Mc Mahan, and Snell. Personnel Psychology, 53, 835-854.

Jaca, C., Viles, E., Mateo, R., \& Santos, J. (2012). Components of sustainable improvement systems: theory and practice. The TQM Journal, 24, 142-154.

Jackson, S. E., Schuler, R. S., \& Jiang, K. (2014). An aspirational framework for strategic human resource management. The Academy of Management Annals, 8, 1-56.

Janssen, O., Van de Vliert, E., \& West, M. (2004). The bright and dark sides of individual and group innovation: A special issue introduction. Journal of Organizational Behavior, 25, $129-145$.

Jiang, K., Lepak, D. P., Hu, J., \& Baer, J. C. (2012). How does human resource management influence organizational outcomes? A meta-analytic investigation of mediating 
mechanisms. Academy of Management Journal, 55, 1264-1294.

Jiang, K., Takeuchi, R., \& Lepak, D. P. (2013). Where do we go from here? New perspectives on the black box in strategic human resource management research. Journal of Management Studies, 50, 1448-1480.

Jung, D. I., Chow, C., \& Wu, A. (2003). The role of transformational leadership in enhancing organizational innovation: Hypotheses and some preliminary findings. The Leadership Quarterly, 14, 525-544.

Kaufman, B. E., \& Taras, D. G. (2010). Employee Participation Through Non-Union Forms of Employee Representation. In: Wilkinson, A., Gollan, P. J., Marchington, M., \& Lewin, D., (Eds) (2010). The Oxford Handbook of Participation in Organization. Oxford University Press.

Kerr, J. L. (2004). The limits of organizational democracy. Academy of Management Executive, 18(3), 81-95.

Kesting, P., Song, L. J., Qin, Z., \& Krol, M. (2016). The role of employee participation in generating and commercialising innovations: insights from Chinese high-tech firms. The International Journal of Human Resource Management, 27, 1059-1081.

Kilgour, M. (2006). Improving the creative process: Analysis of the effects of divergent thinking techniques and domain specific knowledge on creativity. International Journal of Business and Society, 7(2), 79-107.

Kim, H., \& Kang. S. (2013). Strategic HR functions and firm performance: The moderating effects of high-involvement work practices. Asia Pacific Journal of Management, 30, 91-113.

This article is protected by copyright. All rights reserved. 
Kim, J., MacDuffie, J. P., \& Pil, F. K. (2010). Employee voice and organizational performance: Team versus representative influence. Human Relations, 63, 371-394.

Kimberly, J. R., \& Evanisko, M. J. (1981). Organizational innovation: The influence of individual, organizational, and contextual factors on hospital adoption of technological and administrative innovations. Academy of Management Journal, 24, 689-713.

Kleinknecht, R. H. (2015). Employee participation in corporate governance: Implications for company resilience. European Journal of Industrial Relations, 21, 57-72.

Lado, A. A., \& Wilson, M. C. (1994). Human resource systems and sustained competitive advantage: A competency-based perspective. Academy of Management Review, 19, 699-727.

Lavelle, J., P. Gunnigle, \& A. McDonnell. (2010). Patterning Employee Voice in Multinational Companies. Human Relations, 63, 395-418.

Lepak, D. P., \& Snell, S. A. (2002). Examining the human resource architecture: The relationships among human capital, employment, and human resource configurations. Journal of Management, 28, 517-543.

Lepak, D. P., Taylor, M. S., Tekleab, A. G., Marrone, J. A., \& Cohen, D. J. (2007). An examination of the use of high-investment human resource systems for core and support employees. Human Resource Management, 46, 223-246.

Li, Y., Wang, M., van Jaarsveld, D., Lee, G. K., \& Ma, D. (2017). From Employee-Experienced High-Involvement Work System to Innovation: An Emergence-Based Human Resource Management Framework. Academy of Management Journal. Advance online publication.

This article is protected by copyright. All rights reserved. 
Liu, D., Gong, Y., Zhou, J., \& Huang, J. C. (2017). Human resource systems, employee creativity, and firm innovation: The moderating role of firm ownership. Academy of Management Journal, 60, 1164-1188.

Lopez-Cabrales, A., Pérez-Luño, A., \& Cabrera, R. V. (2009). Knowledge as a mediator between HRM practices and innovative activity. Human Resource Management, 48, 485-503.

Marchington, M., \& Suter, J. (2013). Where Informality Really Matters: Patterns of Employee Involvement and Participation (EIP) in a Non-Union Firm. Industrial Relations: A Journal of Economy and Society, 52, 284-313.

Marín-García, J. A., \& Bonavía, T. (2015). Relationship between employee involvement and lean manufacturing and its effect on performance in a rigid continuous process industry. International Journal of Production Research, 53, 3260-3275.

Marín-García, J. A., \& Poveda, Y. B. (2010). The implementation of a continuous improvement project at a Spanish marketing company: a case study. International Journal of Management, 27, 593-606.

Miller, K. I., \& Monge, P. R. (1986). Participation, satisfaction, and productivity: A meta-analytic review. Academy of Management Journal, 29, 727-753.

Mowbray, P. K., Wilkinson, A., \& Tse, H. H. (2015). An integrative review of employee voice: Identifying a common conceptualization and research agenda. International Journal of Management Reviews, 17, 382-400.

Mumford, M. 2011. Handbook of organizational creativity. New York: Academic Press.

National Survey of Democratic Management in Enterprises (2016, March). From: 
http://www.cwgk.org/art/2016/3/17/art_1102_171144.html.

Negassi, S. (2004). R\&D co-operation and innovation a micro-econometric study on French firms. Research Policy, 33, 365-384.

Nembhard, I. M., \& Edmondson, A. C. (2006). Making it safe: The effects of leader inclusiveness and professional status on psychological safety and improvement efforts in health care teams. Journal of Organizational Behavior, 27, 941-966.

Ng, T. W., \& Feldman, D. C. (2012). Employee voice behavior: A meta-analytic test of the conservation of resources framework. Journal of Organizational Behavior, 33, 216-234.

Nyberg, A. J., Moliterno, T. P., Hale Jr, D., \& Lepak, D. P. (2014). Resource-based perspectives on unit-level human capital: A review and integration. Journal of Management, 40, 316-346.

Obstfeld, D. (2005). Social networks, the tertius iungens orientation, and involvement in innovation. Administrative Science Quarterly, 50, 100-130.

Ployhart, R. E., \& Moliterno, T. P. (2011). Emergence of the human capital resource: A multilevel model. Academy of Management Review, 36, 127-150.

Pohler, D., \& Luchak, A. (2015). Are unions good or bad for organizations? The moderating role of management's response. British Journal of Industrial Relations, 53, 423-459.

Qian, C., Cao, Q., \& Takeuchi, R. (2013). Top management team functional diversity and organizational innovation in China: The moderating effects of environment. Strategic Management Journal, 34, 110-120.

Rauch, A., Frese, M., \& Utsch, A. (2005). Effects of Human Capital and Long-Term Human Resources Development and Utilization on Employment Growth of Small-Scale 
Businesses: A Causal Analysis1. Entrepreneurship Theory and Practice, 29, 681-698.

Rogers, E. M. (2010). Diffusion of innovations. New York: Simon and Schuster.

Salancik, G. R., \& Pfeffer, J. (1977). An examination of need-satisfaction models of job attitudes. Administrative Science Quarterly, 22, 427-456.

Sanderson, K. R., Bruk-Lee, V., Viswesvaran, C., Gutierrez, S., \& Kantrowitz, T. (2013). Multitasking: Do preference and ability interact to predict performance at work? Journal of Occupational and Organizational Psychology, 86, 556-563.

Scherer, F. M. (1965). Firm size, market structure, opportunity, and the output of patented inventions. The American Economic Review, 55, 1097-1125.

Scherrer-Rathje, M., Boyle, T. A., \& Deflorin, P. (2009). Lean, take two! Reflections from the second attempt at lean implementation. Business Horizons, 52, 79-88.

Seeck, H., \& Diehl, M. R. (2017). A literature review on HRM and innovation-taking stock and future directions. The International Journal of Human Resource Management, 28(6), 913-944.

Smith, K. G., Collins, C. J., \& Clark, K. D. (2005). Existing knowledge, knowledge creation capability, and the rate of new product introduction in high-technology firms. Academy of Management Journal, 48, 346-357.

Somaya, D., Williamson, I. O., \& Lorinkova, N. (2008). Gone but not lost: The different performance impacts of employee mobility between cooperators versus competitors. Academy of Management Journal, 51, 936-953.

Subramaniam, M., \& Youndt, M. A. (2005). The influence of intellectual capital on the types of innovative capabilities. Academy of Management journal, 48, 450-463.

This article is protected by copyright. All rights reserved. 
Timming, A. R. (2015). The 'reach'of employee participation in decision-making: exploring the Aristotelian roots of workplace democracy. Human Resource Management Journal, 25, 382-396.

Tushman, M. L., \& Anderson, P. (1986). Technological discontinuities and organizational environments. Administrative Science Quarterly, 31, 439-465.

Wang, T., Zhao, B., \& Thornhill, S. (2015). Pay dispersion and organizational innovation: The mediation effects of employee participation and voluntary turnover. Human Relations, 68, 1155-1181.

Wayne, S. J., Shore, L. M., \& Liden, R. C. (1997). Perceived organizational support and leader-member exchange: A social exchange perspective. Academy of Management Journal, 40, 82-111.

Wilkinson, A., \& Dundon, T. (2010). Direct Employee Participation. In: Wilkinson, A., Gollan, P. J., Marchington, M., \& Lewin, D., (Eds) (2010). The Oxford Handbook of Participation in Organization. Oxford University Press.

Wilkinson, A., \& Fay, C. (2011). New times for employee voice? Human Resource Management, 50(1), 65-74.

Wilkinson, A., Townsend, K., \& Burgess, J. (2013). Reassessing employee involvement and participation: Atrophy, reinvigoration and patchwork in Australian workplaces. Journal of Industrial Relations, 55(4), 583-600.

Wright, P. M., \& Boswell, W. R. (2002). Desegregating HRM: A review and synthesis of micro and macro human resource management research. Journal of Management, 28, 247-276.

This article is protected by copyright. All rights reserved. 
Wright, P. M., \& McMahan, G. C. (2011). Exploring human capital: putting 'human' back into strategic human resource management. Human Resource Management Journal, 21, 93-104.

Wright, P. M., Coff, R., \& Moliterno, T. P. (2014). Strategic human capital crossing the great divide. Journal of Management, 40, 353-370.

Xiao, Z., \& Björkman, I. (2006). High commitment work systems in Chinese organizations: A preliminary measure. Management and Organization Review, 2, 403-422.

Xing, Y., Liu, Y., \& Cooper, S. C. L. (2018). Local Government as Institutional Entrepreneur: Public-Private Collaborative Partnerships in Fostering Regional Entrepreneurship. British Journal of Management. Advance online publication.

Youndt, M. A., Subramaniam, M., \& Snell, S. A. (2004). Intellectual capital profiles: An examination of investments and returns. Journal of Management Studies, 41, 335-361.

Zatzick, C. D., \& Iverson, R. D. (2006). High-involvement management and workforce reduction: competitive advantage or disadvantage? Academy of management Journal, 49, 999-1015.

Zhang, X., \& Bartol, K. M. (2010). Linking empowering leadership and employee creativity: the influence of psychological empowerment, intrinsic motivation, and creative process engagement. Academy of Management Journal, 53, 107-128.

Zhou, K. Z., Gao, G. Y., \& Zhao, H. (2017). State ownership and firm innovation in China: An integrated view of institutional and efficiency logics. Administrative Science Quarterly, 62, 375-404.

Zhou, Y., Hong, Y., \& Liu, J. (2013). Internal commitment or external collaboration? The 
impact of human resource management systems on firm innovation and performance. Human Resource Management, 52, 263-288.

This article is protected by copyright. All rights reserved. 
Table 1. EFA factor loadings of direct voice mechanism and corporate governance participation items

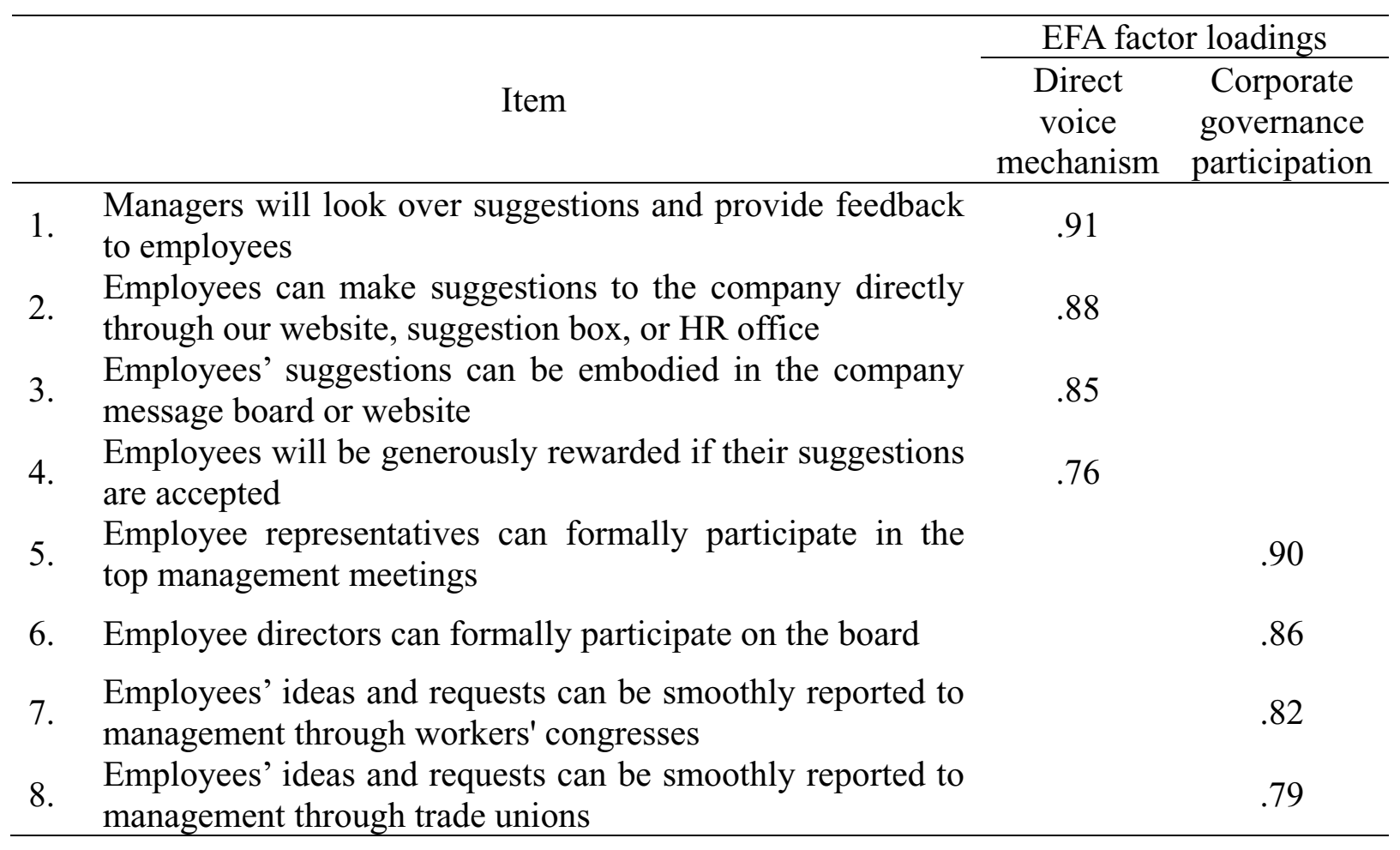


Table 2. Means, standard deviations, correlations, and reliabilities

\begin{tabular}{|c|c|c|c|c|c|c|c|c|c|c|}
\hline & $\mathrm{M}$ & SD & 1 & 2 & 3 & 4 & 5 & 6 & 7 & 8 \\
\hline 1. $R \& D$ input & 16.32 & 17.23 & & & & & & & & \\
\hline $\begin{array}{l}\text { 2. Industry } \\
\text { (manufacturing=1) }\end{array}$ & 0.66 & 0.48 & -.16 & & & & & & & \\
\hline $\begin{array}{l}\text { 3. Industry } \\
(\text { service }=1)\end{array}$ & 0.30 & 0.46 & .14 & $-.90 * *$ & & & & & & \\
\hline 4. Firm size ${ }^{a}$ & 5.45 & 1.27 & $-.36^{* *}$ & $.19^{*}$ & -.10 & & & & & \\
\hline 5. HPWS & 3.50 & 0.54 & .05 & -.17 & .16 & .08 & $(.83)$ & & & \\
\hline $\begin{array}{l}\text { 6. Corporate governance } \\
\text { participation }\end{array}$ & 3.32 & 0.85 & -.01 & .06 & -.09 & .10 & $.45^{* *}$ & $(.88)$ & & \\
\hline 7. Direct voice mechanism & 3.64 & 0.68 & -.13 & -.03 & .07 & $.19 *$ & $.63 * *$ & $.56^{* *}$ & (.89) & \\
\hline 8. Human capital & 3.08 & 0.72 & -.03 & -.08 & .06 & $.32 * *$ & -.04 & -.19 & -.06 & \\
\hline 9. Organizational innovation ${ }^{b}$ & 23.90 & 19.31 & $.44 * *$ & .13 & -.14 & -.14 & .08 & .11 & .12 & -.04 \\
\hline
\end{tabular}

${ }^{a}$ Natural logarithm transformation of total number of employees

b Transformation into percentage

Note: Reliabilities of scales are boldfaced noted in the diagonals.

$* p<.05$

$* * p<.01$ 
Table 3. Results of regression analyses for the interaction effects of HPWS, corporate governance participation/ direct voice mechanism, and human capital on organizational innovation

\begin{tabular}{|c|c|c|c|c|}
\hline \multirow{2}{*}{ Variables } & \multicolumn{4}{|c|}{ Organizational innovation $^{\mathrm{a}}$} \\
\hline & Model 1 & Model 2 & Model 3 & Model 4 \\
\hline \multicolumn{5}{|l|}{ Control variables } \\
\hline R\&D input & $.53 * *$ & $.56 * *$ & $.57 * *$ & $.55^{* *}$ \\
\hline Industry (Manufacturing) & 3.60 & 2.40 & 2.33 & .33 \\
\hline Industry (Service) & -5.33 & -7.13 & -7.71 & -9.07 \\
\hline Firm size & .09 & -.43 & -.70 & -1.02 \\
\hline \multicolumn{5}{|l|}{ Independent variables } \\
\hline HPWS & & -1.13 & -1.63 & -1.73 \\
\hline \multicolumn{5}{|l|}{ Moderator } \\
\hline $\begin{array}{l}\text { Corporate governance } \\
\text { participation }\end{array}$ & & -.08 & -.22 & -1.71 \\
\hline Direct voice mechanism & & $4.73 \dagger$ & $4.69 \dagger$ & $5.89 *$ \\
\hline Human capital & & .11 & .11 & .71 \\
\hline \multicolumn{5}{|l|}{ Two-way Interaction } \\
\hline $\begin{array}{l}\text { HPWS } \times \text { corporate } \\
\text { governance participation }\end{array}$ & & & .68 & .82 \\
\hline HPWS $\times$ human capital & & & -.90 & $-4.51 \dagger$ \\
\hline $\begin{array}{l}\text { Corporate governance } \\
\text { participation } \times \text { human capital }\end{array}$ & & & .38 & .38 \\
\hline $\begin{array}{l}\text { HPWS } \times \text { direct voice } \\
\text { mechanism }\end{array}$ & & & 1.63 & .64 \\
\hline $\begin{array}{l}\text { Direct voice mechanism } \times \\
\text { human capital }\end{array}$ & & & 1.85 & 3.28 \\
\hline $\begin{array}{l}\text { Three-way interaction } \\
\text { HPWS } \times \text { corporate } \\
\text { governance participation } \times \\
\text { human capital }\end{array}$ & & & & $9.50 * *$ \\
\hline $\begin{array}{l}\text { HPWS } \times \text { direct voice } \\
\text { mechanism } \times \text { human capital }\end{array}$ & & & & $-7.61 *$ \\
\hline$R^{2}$ & .24 & .28 & .30 & .36 \\
\hline$\Delta R^{2}$ & - & .04 & .02 & $.06^{*}$ \\
\hline
\end{tabular}

${ }^{\mathrm{a}}$ Transformation into percentage 
$\dagger p<.10$

$* p<.05$

$* * p<.01$

Note: Two-tailed test was performed.

This article is protected by copyright. All rights reserved. 
Figure 1. Theoretical framework

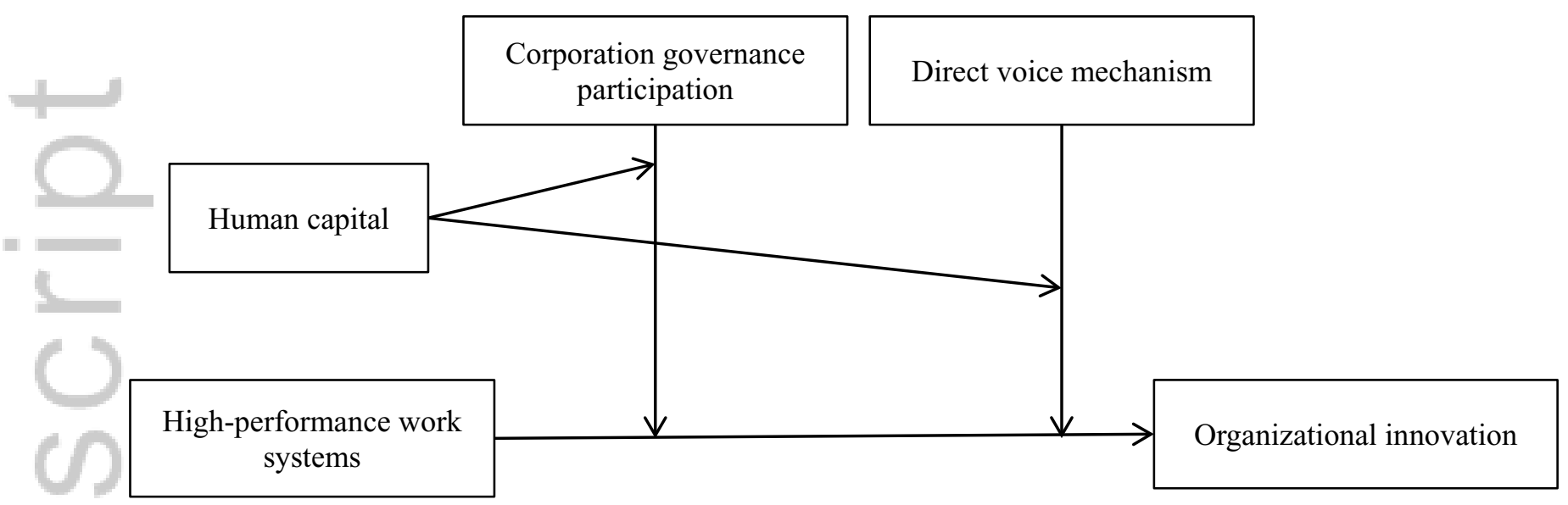


Figure 2a \& 2b. The moderating effect of direct voice mechanism and human capital on the relationship between HPWS and organizational innovation

Figure 2a

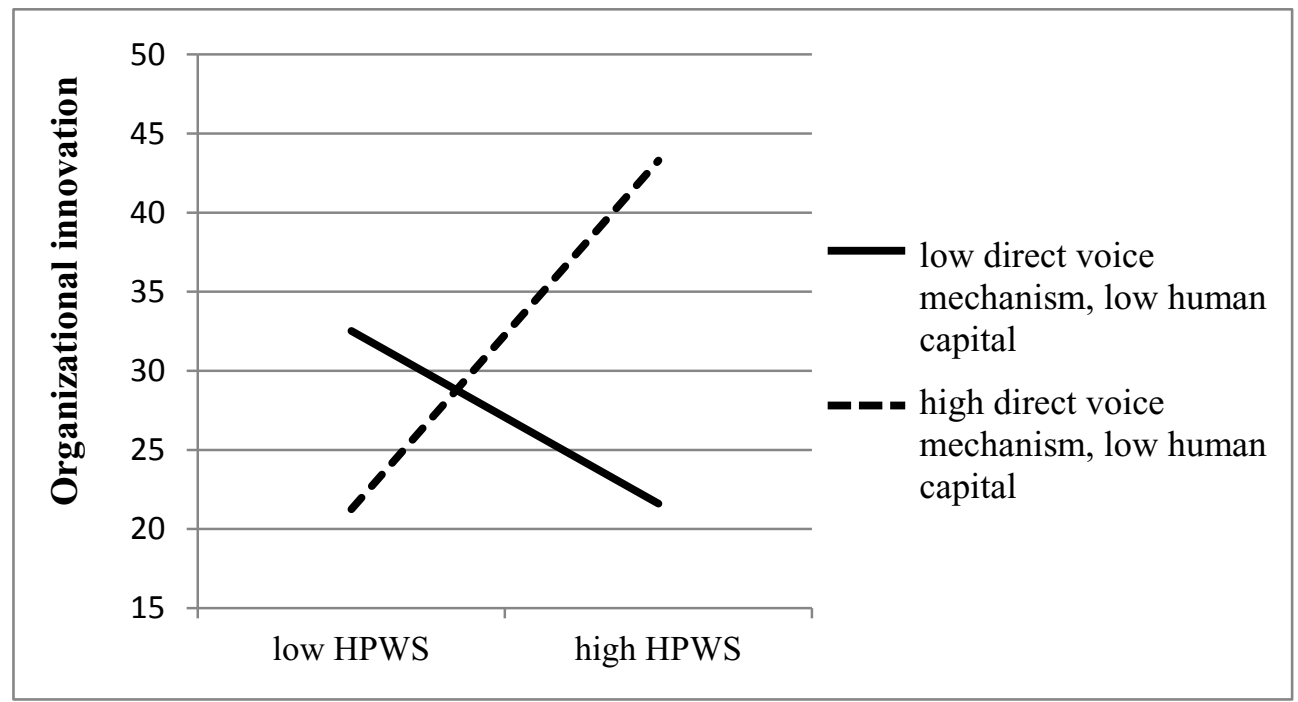

Figure 2b

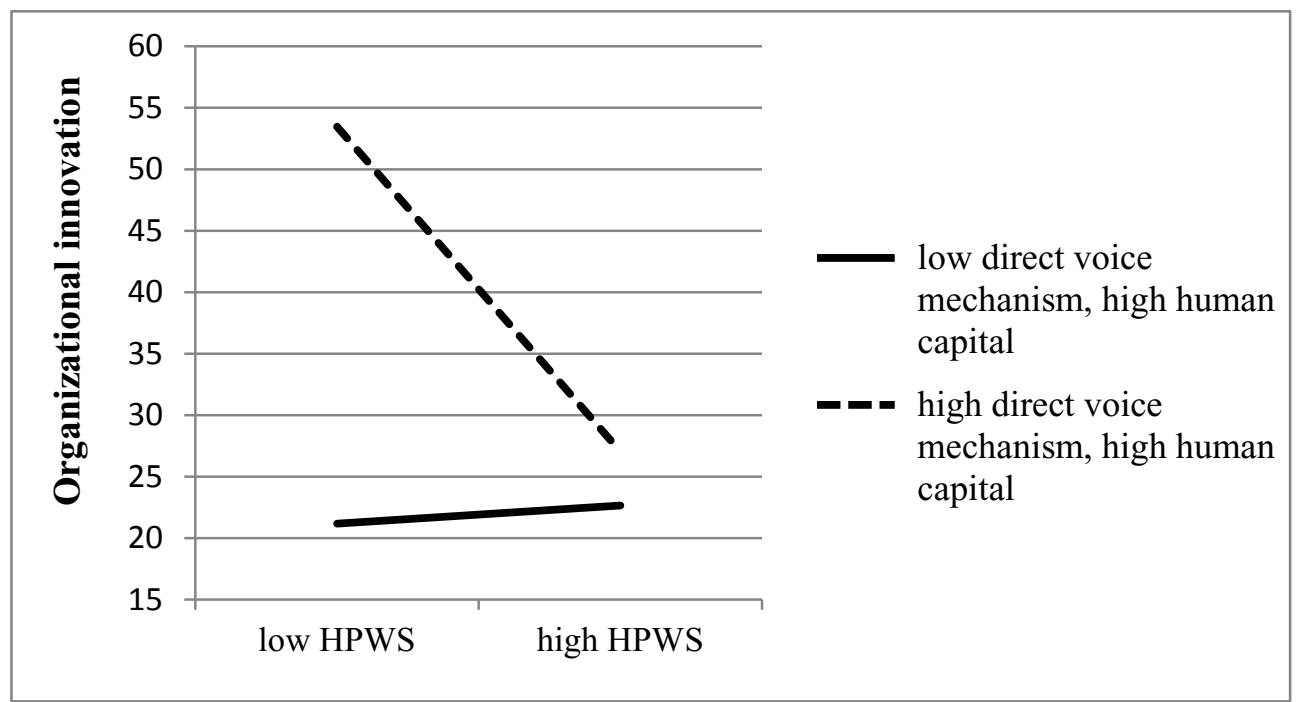

This article is protected by copyright. All rights reserved. 
Figure 3a \& 3b. The moderating effect of corporate governance participation and human capital on the relationship between HPWS and organizational innovation

Figure 3a

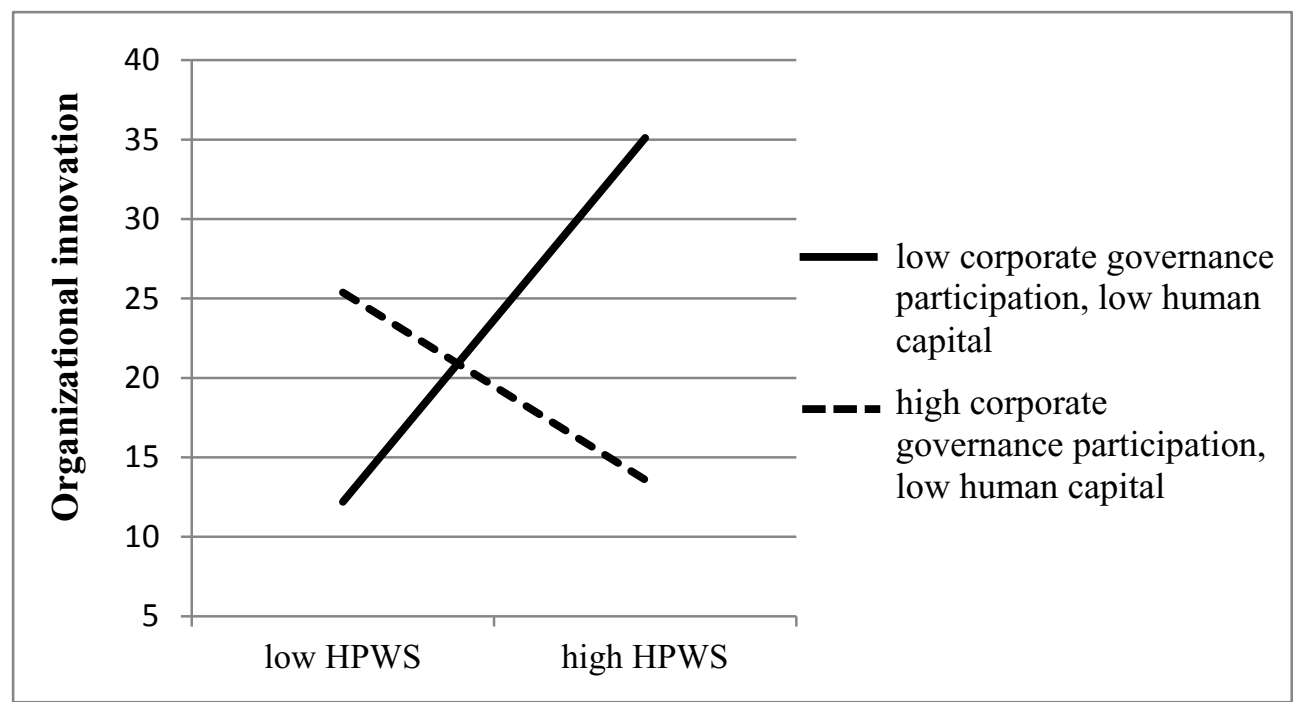

Figure 3b

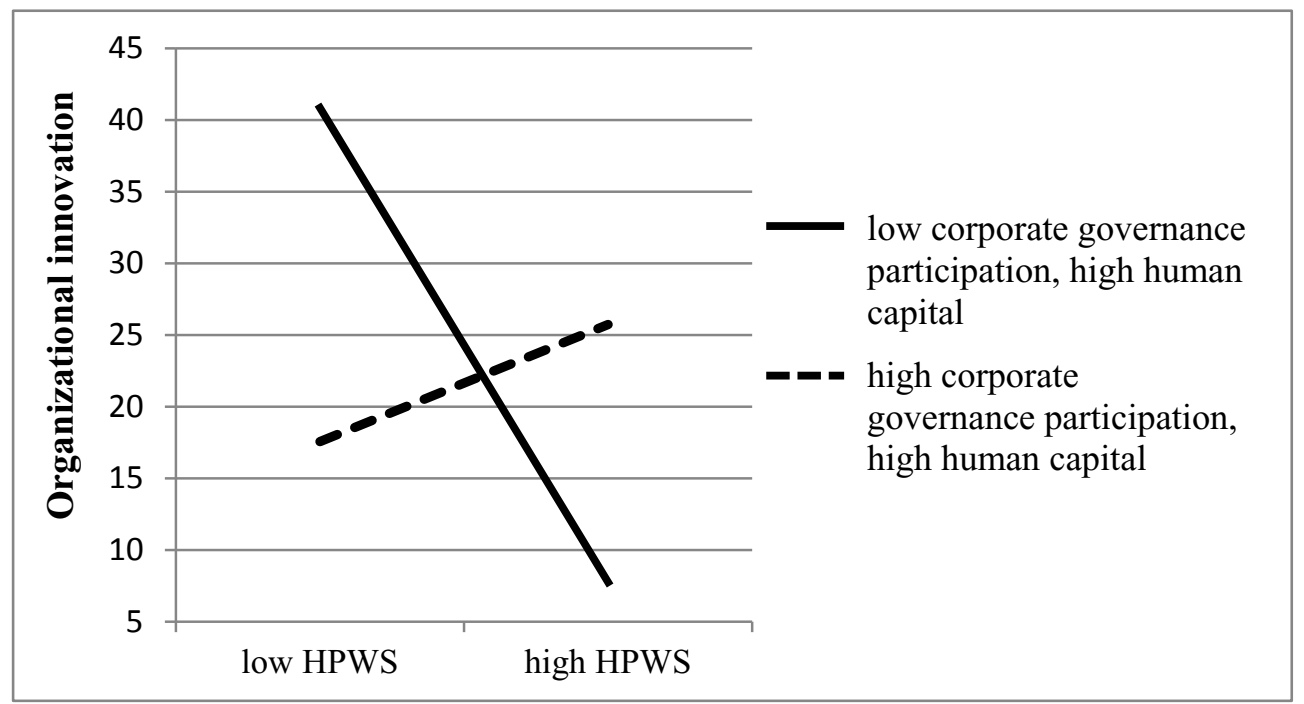

This article is protected by copyright. All rights reserved. 
This article is protected by copyright. All rights reserved. 


\section{APPENDIX}

Comparison of studies related to this research

\begin{tabular}{|c|c|c|}
\hline Study & Findings & Comparison \\
\hline $\begin{array}{l}\text { Bryson, Forth, } \\
\& \text { Kirby }(2005)\end{array}$ & $\begin{array}{l}\text { (1) High-involvement management practices have a } \\
\text { positive impact on labor productivity only in unionized } \\
\text { workplaces, } \\
\text { (2) In unionized workplaces, high-involvement } \\
\text { management practices do not have a significant impact } \\
\text { on financial performance }\end{array}$ & \multirow{2}{*}{$\begin{array}{l}\text { (1) Conflicting results with } \\
\text { respect to the interaction } \\
\text { effects of HRM and union on } \\
\text { firm performance. } \\
\text { (2) Human capital is not } \\
\text { considered. } \\
\text { (3) Focuses only on union, } \\
\text { without considering other } \\
\text { forms of indirect participation. }\end{array}$} \\
\hline $\begin{array}{l}\text { Kim \& Kang } \\
(2013)\end{array}$ & $\begin{array}{l}\text { The positive effect of a strategic HR function on firm } \\
\text { performance is strengthened by union participation in } \\
\text { company strategy. }\end{array}$ & \\
\hline $\begin{array}{l}\text { Marchington \& } \\
\text { Suter (2013) }\end{array}$ & $\begin{array}{l}\text { Multiple forms of employee involvement and } \\
\text { participation are complementary and not mutually } \\
\text { exclusive. Formal and informal employee participation } \\
\text { in decision-making can be combined, either in parallel } \\
\text { for different issues or in sequence for the same issues. }\end{array}$ & $\begin{array}{l}\text { (1) Human capital is not } \\
\text { considered. } \\
\text { (2) HRM is not considered. }\end{array}$ \\
\hline Gallie (2013) & $\begin{array}{l}\text { (1) Trade union strength makes no difference to the } \\
\text { effects of direct participation. } \\
\text { (2) The strength of direct participation's implications } \\
\text { varies between employees of different gender, } \\
\text { occupational class, and ability to use personal } \\
\text { initiative at work. }\end{array}$ & $\begin{array}{l}\text { (1) HRM is not considered } \\
\text { (2) Although indicating the } \\
\text { effects of human capital in the } \\
\text { functioning of employee } \\
\text { participation, this study does } \\
\text { not examine human capital } \\
\text { directly. } \\
\text { (3) Focuses only on union, } \\
\text { without considering other } \\
\text { forms of indirect participation. }\end{array}$ \\
\hline Timming (2015) & $\begin{array}{l}\text { 'Excellent' employees who have superior educational } \\
\text { attainment deserve more opportunities to participate in } \\
\text { decision-making than the rest of the workforce. }\end{array}$ & $\begin{array}{l}\text { (1) HRM is not considered. } \\
\text { (2) Although indicating the } \\
\text { effect of human capital for } \\
\text { employee participation, this } \\
\text { study does not test human } \\
\text { capital's impact empirically. }\end{array}$ \\
\hline
\end{tabular}




\section{University Library}

\section{- M I I N E R VA \\ A gateway to Melbourne's research publications}

Minerva Access is the Institutional Repository of The University of Melbourne

Author/s:

Zhou, Y;Fan, X;Son, J

Title:

How and when matter: Exploring the interaction effects of high-performance work systems, employee participation, and human capital on organizational innovation

Date:

2019-05-01

\section{Citation:}

Zhou, Y., Fan, X. \& Son, J. (2019). How and when matter: Exploring the interaction effects of high-performance work systems, employee participation, and human capital on organizational innovation. Human Resource Management, 58 (3), pp.253-268. https:// doi.org/10.1002/hrm.21950.

Persistent Link:

http://hdl.handle.net/11343/286827 